\title{
TOMASZ SZELĄG
}

Uniwersytet Jagielloński

\section{KARY I ODZNACZENIA W RZYMSKIM PRAWIE WOJSKOWYM}

Żelazna dyscyplina, karność, poświęcenie to przymioty armii rzymskiej, dzięki którym mała pasterska osada rozrosła się do rozmiarów potężnego imperium. Oprócz świetnej, ewoluującej przez wieki organizacji armii, decydujące znaczenie w tym rozwoju miał rozbudowany system kar i odznaczeń wojskowych. Zagadnienia te były wielokrotnie przedmiotem badań, jako wchodzące w zakres rzymskiego prawa karnego wojskowego. Niestety, stopień zainteresowania tą dziedziną prawa publicznego przez długie lata był ograniczony. W romanistyce polskiej na temat wojskowego prawa karnego istnieje zaledwie jedna obszerniejsza praca autorstwa G. Kuleczki ${ }^{1}$. Badając kwestię kar i odznaczeń w armii rzymskiej korzystać należy więc $z$ opracowań znacznie starszych, jak prace J. Marquardta i Th. Mommsena ${ }^{2}$, czy też zbyt surowo oceniona przez G. Kuleczkę, praca C. E. Branda pt. „Roman Military Law"3.

${ }^{1}$ G. KuleczKa, Studia nad rzymskim wojskowym prawem kamym, Poznań 1974.

${ }^{2}$ J. Marquardt, TH. Mommsen, Handbuch der römischen Alterthümer, I-VII, Leipzig 1871-1887 (TH. Mommsen, I-III: Römisches Staatsrecht, J. MARQuARDT, IV-VI: Römische Staatsverwaltung i VII: Das Privatleben der Römer).

${ }^{3}$ C. E. BRAND, Roman Military Law, Austin 1968. 
Na tych właśnie opracowaniach badaczy oparłem się przy dokonaniu analizy sposobów motywowania i karania żołnierzy w rzymskiej armii.

Armia rzymska, jako gwarant i siła realizująca politykę zagraniczną i wewnętrzną państwa, wymagała sprawnej organizacji zapewniającej odpowiednią dyscyplinę wojskową. Przestępstwa w wojsku jako godzące w interesy całego państwa musiały być więc surowo i natychmiastowo karane. Stąd też cały wachlarz środków represji karnej, które stosowano w wojsku rzymskim wobec żołnierzy dopuszczających się wykroczeń.

Bardzo przejrzystego podziału kar, występujących w rzymskim prawie wojskowym, dokonał J. Marquardt w Römische Staatsverwaltung ${ }^{4}$, wymieniając ich pięć głównych kategorii.

Podstawowym rodzajem dyscyplinowania żolnierzy, obok kar cielesnych, byly kary majątkowe (poena pecuniaria). Proporcjonalnie najlżejszą z nich było pozbawienie zaplaty, kwalifikowanym zaś rodzajem tegoż pozbawienia, było pominięcie zasług żolnierza w poszczególnych kampaniach, w szczególności przy rozdzielaniu nagród na rzecz weteranów ${ }^{5}$. Istniała również możliwość zajęcia majątku żołnierza ${ }^{6}$.

Drugim rodzajem kar była powszechnie znana degradacja (gradus deiectio $)^{7}$, jak również przeniesienie do innego rodzaju wojsk

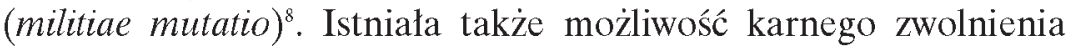
z wojska (missio ignominiosa).

\section{${ }^{4}$ C. E. BRAND, op. cit., s. 104-106.}

${ }^{5}$ Por. Suet., Aug. 24: „Jeśli inne legiony zbyt natarczywie domagały się wysługi lat, zwalniał, ale bez wypłaty wysłużonych nagród”, przekł. J. Niemirska-PliszCZYŃska, Swetoniusz, Żywoty Cezarów, Wroctaw, 1960, s. 74; por. też C. E. BRAND, op. cit., s. 104.

${ }^{6}$ G. KulecZKA, op. cit., s. 103.

${ }^{7}$ Val. Max. 2,7,4.

${ }^{8}$ Front., Strat. 4,1,18: Appii Claudii sententia senatus eos, qui a Pyrrho, rege Epirotarum, capti et postea remissi erant, equites ad pedites redegit, pedites ad levem armaturam, omnibus extra vallum iussis tendere, donec bina hostium spolia singuli referrent.

${ }^{9}$ Front. Strat. 4,1,37: M. Antonius, cum agger ab hostibus incensus esset, ex his, qui in opere fuerant, duarum cohortium militem decimavit et in singulos ex his 
Kary hańbiące (jako kary publicznego pohańbienia zwane ignominia) dotykały zarówno całych jednostek wojskowych, jak i poszczególnych żołnierzy. Oddziały najczęściej karane były przydzielaniem jęczmienia zamiast stałych racji pszenicy oraz nakazem rozbijania namiotów poza granicami regularnego obozu rzymskiego ${ }^{10}$.

Ciekawe przykłady tego rodzaju kary podaje Swetoniusz. Wymienia bowiem taką karę, jak całodniowe stanie przed namiotem wodza w samej tylko tunice, $\mathrm{z}$ grudką ziemi w wyciągniętej dło$\mathrm{ni}^{11}$. Z kolei Marquardt do kar hańbiących zalicza: zakaz spożywania posiłków z towarzyszami z oddziału, jedzenie lub picie na stojąco, czy stanie boso w pewnych miejscach publicznych przez określony czas ${ }^{12}$.

Interesującym rozwinięciem stosowania kar hańbiących wobec żołnierzy było ich egzekwowanie wobec osób cywilnych, uchylających się od służby wojskowej. W takich przypadkach konsulowie korzystali z reguł prawa karnego wojskowego, mimo iż dane działania dotyczyły osób jeszcze nie będących żołnierzami. Do najczęściej stosowanych wówczas kar należały: konfiskaty mienia, chłosta, uwięzienie, sprzedaż w niewolę oraz, po wcieleniu do wojska, przedłużenie lub obostrzenie odbywanej służby wojskowej ${ }^{13}$.

Podstawowym rodzajem kar cielesnych była chłosta (castigatio). W niektórych opracowaniach znajdujemy pogląd uznający chłostę za środek dyscyplinujący, a nie karę, a to z powodu jej częstego wykonywania i stosowania nawet przy bardzo błahych wykrocze-

centuriones animadvertit, legatum cum ignominia dimisit, reliquis ex legione hordeum dari iussit.

${ }^{10}$ C. E. BRAND, op. cit., s. 104.

${ }^{11}$ Suet., Aug. 24: „Za inne rodzaje wykroczeń wyznaczał różne hańbiące kary, jak np. kazal stać przez caly dzień przed namiotem wodza, nieraz tylko w tunikach i bez pasa, niekiedy z tyką dziesięciostopową lub nawet z garścią darni w ręce", przekł. J. NIEMIRSKA-PLISZCZYŃSKA, op. cit., s. 74.

${ }^{12}$ C. E. BRAND, op. cit., s. 104-105.

${ }^{13}$ G. KulECZKA, op. cit., s. 104. 
niach ${ }^{14}$. Wykonywana była bowiem w taki sam sposób zarówno wobec żołnierzy wyższej jak i niższej rangi, czy też bez względu na pozycje społeczną delikwenta ${ }^{15}$. Tak np. Marek Aureliusz Kotta, konsul z roku 74 p.n.e., prowadzący wespół z Lukullusem wojnę przeciwko Mitrydatesowi ${ }^{16}$, zasłynął rozkazem wychłostania trybuna pochodzącego $\mathrm{z}$ wysoko postawionego rodu za niewłaściwe wypełnianie obowiązków, a także tym, że chłostą ukarał również jednego ze swych krewnych, który popełnił wykroczenie podczas zastępowania nieobecnego w obozie konsula ${ }^{17}$.

Kary cielesne były często traktowane również jako złagodzenie kary śmierci za najpoważniejsze wykroczenia przeciwko dyscyplinie wojskowej. Taką karą było np. obcięcie rąk, stosowane przeciwko niektórym uciekinierom, szpiegom czy złodziejom.

W niezwykle surowym rzymskim prawie wojskowym okresu republiki często wykonywaną karą była kara śmierci (poena capitis). Wykonywano ją najczęśsiej poprzez ścięcie toporem lub mieczem, po uprzedniej chłoście rózgami liktorskimi. Zaostrzone sposoby wykonania kary śmierci dotyczyły tylko niektórych przestępstw wojskowych, zaliczanych do najpoważniejszych. Tak więc zdrajcy i dezerterzy przed uśmierceniem poddawani byli torturom, a często rzucano ich na pożarcie zwierzętom lub krzyżowano. Kara śmierci za dezercję groziła najczęściej dopiero w przypadku recydywy. Pierwszy przypadek dezercji i ewentualne dalsze okoliczności lagodzące mogły nawet doprowadzić do całkowitego uwolnienia żołnierza od zagrożenia ukaraniem śmiercią. Jednakże zazwyczaj dezerterzy nie mogli liczyć na złagodzenie kary. Widać to na przykładzie 370 zbiegów z armii podczas wojny z Hannibalem, którzy ujęci, zostali z rozkazu konsula Kwintusa Fabiusza wychłostani, a następnie strąceni ze Skały Tarpejskiej.

${ }^{14}$ G. Kuleczka, op. cit., s. 103; M. FuhrmanN, s. v. Verbera, «RE Suppl.» 9 (1962), szp. 1125.

${ }^{15}$ C. E. BRAND, op. cit., s. 105.

${ }^{16}$ M. CRAWford, Rzym w okresie republiki, przekł. J. RoHoziński, Warszawa 2004, s. 164-165.

${ }^{17}$ C. E. BRAND, op. cit., s. 105. 
$\mathrm{Na}$ równi z dezercją traktowane było pozbycie się lub utrata broni przez żołnierza. Chodziło w tym wypadku jednak nie o jakiekolwiek części rynsztunku żołnierskiego, ale o uzbrojenie podstawowe - miecz, tarczę czy pancerz ${ }^{18}$.

Szczególnym, albowiem dotyczącym większej ilości żołnierzy, był sposób wykonania kary śmierci przez dziesiątkowanie (decimatio). Przykładowo Lucjusz Aproniusz, dowodzący legionem podczas afrykańskiego buntu Numidyjczyka Takfarynasa (17-24 n.e. $)^{19}$, przywrócił kary z okresu wczesnej republiki i, ze zhańbionej ucieczką z pola walki kohorty, rozkazał uśmiercić przez supplicium fustuarium $^{20}$ co dziesiątego, wybranego losowo żołnierza. Kara ta polegała na biciu kijami bądź rózgami na śmierć.

Istniała także swoista odmiana wykonania kary śmierci przez fustuarium. Egzekwowana była wobec obwinionego przez samych żołnierzy. Podobnie jak przy dziesiątkowaniu, polegała na biciu skazanego kijami i kamienowaniu ${ }^{21}$. Oprócz podstawowego znaczenia tej kary, miała ona także wymiar hańbiący. Powierzenie wykonywania egzekucji samym żołnierzom wskazywać miało bowiem na potępienie przez nich czynu skazanego.

Ponadto występowały też inne sposoby wykonywania kary śmierci, stosownie do decyzji dowodzącego. Karana śmiercią była także niesubordynacja (contumacia). Przekazy źródłowe o charakterze jurydycznym $^{22}$ wskazują, że był to rodzaj przestępstwa o zdecydo-

${ }^{18}$ G. KuleczKA, op. cit., s. 86-87.

${ }^{19}$ C. WELls, Cesarstwo rzymskie, przekł. T. Duliński, Warszawa 2005, s. 180-181.

${ }^{20}$ Tac., ann. 3,21: „Kiedy się o tym Lucjusz Aproniusz dowiedział- bo on był Kamillusa następcą - zaniepokojony bardziej hańbą swoich niż sławą wroga, każe według rzadkiego już w tych czasach i przypominającego starożytność trybu postępowania - co dziesiątego człowieka ze zhańbionej kohorty losem wybrać i na śmierć zachlostać. Surowość ta tak wielki wywarła skutek, że chorągiew weteranów licząca nie więcej jak pięciuset żołnierzy rozbiła te same gromady Takfarynasa, które warowne miejsca zwane Thala zaatakowaly", przekł. S. HAMMER, Tacyt, Dzieta, Warszawa 2004, s. 129.

${ }^{21}$ G. KuleCZKA, op. cit., s. 101.

${ }^{22}$ D. $49,16,5,8$; D. $49,16,6,1$; D. 49,16,3,17-18; D. $49,16,13,4$. 
wanie najszerszym zakresie znamion, często zależny od subiektywnej oceny dowódców.

Do legendy przeszła choćby kara śmierci orzeczona przez konsula Tytusa Manliusza Torkwatusa wobec własnego syna, za złamanie rozkazu podczas wojny z Latynami²3. Młody żołnierz stoczył zwycięski pojedynek z butnie zachowującym się wrogiem, jednak zamiast spodziewanej pochwały, ze strony ojca spotkała go surowa kara. Został ścięty toporem za niesubordynację i złamanie rozkazów dowódcy. Liwiusz podsumowując te wydarzenia stwierdził, że „tzw. Rozkazy Manliuszowe budziły postrach nie tylko w chwili obecnej, lecz stanowiły także ostrzegający przykład na przyszłość" 24.

Postępowanie karne za niesubordynację toczyło się zapewne w obecności całego oddziału, przed którym przedstawiano zgromadzone dowody, a w wydawaniu wyroku uczestniczyli żolnierze ${ }^{25}$.

Jak zaznacza C. E. Brand, występowało o wiele więcej kar, które nie mieszczą się w ramach klasyfikacji Marquardta. Wśród nich wymienić należy: wygnanie stałe lub na pewien określony czas (w tym zesłanie na wyspę), czy też capitis deminutio maxima żołnierza, który stawał się w ten sposób niewolnikiem.

Niebywałe sukcesy armii rzymskiej nie zależały jednak tylko od niezwykle surowych kar utrzymujących w szeregach żelazną dyscyplinę. Czynnikiem, który miał na to wpływ, pomijając sprawy organizacji czy taktyki, był bowiem również rozbudowany system nagradzania i odznaczania żołnierzy.

Podstawowymi odznaczeniami dla żolnierzy i niższych oficerów, były nagrody rzeczowe, takie jak: naszyjniki (torques), naramienni-

${ }^{23}$ A. KRawCZuk, Kronika Rzymu i Cesarstwa Rzymskiego, Warszawa, 1997, s. 65. Od tego niezwykle surowego rozkazu powstało określenie Manliana imperia dotyczące poleceń obowiązujących bezwzględnie, bez żadnych odstępstw.

${ }^{24}$ Liv. 18,8,7, przekł. W. StRZELecki, Tytus Liwiusz, Dzieje od założenia miasta Rzymu, Wrocław 2004, s. 252-253.

${ }^{25}$ G. KuleczKa, op. cit., s. 67. 
ki (armillae), klamry, sprzączki (fibulae) $)^{26}$, których zadaniem było wyróżnianie najlepszych żołnierzy spośród regularnie umundurowanych oddziałów. Najczęściej jednak wyższych oficerów, a w wyjątkowych przypadkach również zwykłych żołnierzy, odznaczano za konkretne zasługi bądź osiągnięcia specjalnymi wieńcami zakładanymi na głowę lub noszonymi w dłoni zwanymi koronami (coronae). Odróżniano przy tym, jako najwyższą nagrodę - wieniec $\mathrm{z}$ trawy (corona graminea), przyznawany za ocalenie armii lub oblężonego miasta ${ }^{27}$. Natomiast „korona obywatelska” (corona civi$c a), \mathrm{z}$ wieńca dębowego, przyznawana była żołnierzowi za uratowanie życia obywatela rzymskiego.

Przykład taki przytacza Tacyt opisując czyn żołnierza, Rufusa Helwiusza, który ocalił życie wspóttowarzysza i otrzymał za to od Aproniusza naszyjnik, włócznię (hasta pura - specjalną włócznię bez żelaznego ostrza), a od samego Tyberiusza koronę obywatel$\mathrm{skąa}^{28}$. Ponadto istniały: corona muralis - złoty wieniec, która przysługiwała temu, który pierwszy wdarł się na mury obleganego miasta; corona castrensis sive vallaria - dla żołnierza, który pierwszy wkroczył do nieprzyjacielskiego obozu; corona navalis - dla bohatera, który pierwszy wskoczył na wrogi okręt.

Oprócz tego stałego katalogu odznaczeń pojawiały się oczywiście nagrody pieniężne, zależące od szczodrości wodza. Niezwykle hojnym dowódcą potrafił być Juliusz Cezar. Umiał on znakomicie balansować pomiędzy sprawiedliwym karaniem a docenianiem męstwa swoich żołnierzy. Posiadanie takiej umiejętności było nie-

${ }^{26}$ C. E. BRAND, op. cit., s. 107.

${ }^{27}$ C. E. BRAND, op. cit., s. 108 określa taką nagrodę jako corona obsidionalis dla wodza, który uwolnił żołnierzy $\mathrm{z}$ oblężenia. Byla ona robiona $\mathrm{z}$ trawy rosnące $j$ w miejscu oblężenia i nadawana wodzowi przez uratowanych żolnierzy.

${ }^{28}$ Tac., ann. 3,21: „W tej bitwie Rufus Helwiusz, prosty żołnierz, zdobył chwałę z powodu ocalenia ziomkowi życia i otrzymał w darze od Aproniusza naszyjnik i włócznię. Cezar dodał mu koronę obywatelską, ubolewając raczej niż urażony, że i jej mu także Aproniusz prawem prokonsula nie użyczył.", przekł. S. HAMMER, op. cit., s. 129. 
zwykle ważne, gdy wojsko coraz częściej potrafiło wykorzystać dla siebie tarcia pomiędzy wyższymi sferami politycznymi, co potwierdza przykład Marka Licyniusza Lukullusa, wielkiego, lecz niezwykle surowego wobec żołnierzy wodza, który przez sześć pierwszych lat III wojny z Mitrydatesem (od 74 r. p.n.e.) odnosił sukcesy, by w latach 68-66 p.n.e. bezczynnie marnotrawić wcześniejsze zwycięstwa w wyniku rozruchów i buntu w wojsku. W efekcie Lukullus został odwołany do Rzymu ${ }^{29}$, a późniejszy splendor za dokończenie praktycznie rozstrzygniętej już kampanii, spadł na Gnejusza Pompejusza. Natomiast Lukullus na zasłużony tryumf musiał czekać jeszcze do 63 r. p.n.e..$^{30}$

Cezar natomiast niezwykle hojnie obdarzył centuriona Scaevę, który w bitwie pod Dyrrachium wykazał się bohaterstwem i w nagrodę otrzymal 200000 sesterców oraz awans o czterdzieści dwa stopnie, aż do rangi pierwszego centuriona I kohorty (centurio primus pilus). Także po tej bitwie najodważniejszym żołnierzom nakazał Cezar wypłacić podwójny żołd i przydzielił dodatkowe racje zboża ${ }^{31}$.

Jedną z podstawowych nagród dla każdego żołnierza mógł być awans, choć nie zawsze tak błyskotliwy jak w przypadku przedstawionym powyżej. Analogicznie do wskazanej wcześniej kary w postaci przeniesienia do gorszego oddziału, istniała możliwość promocji do lepszej jednostki.

29 A. Keaverney, Lukullus, przekł. A. Zió£Kowski, Warszawa 1998, s. $128-140$.

${ }^{30}$ A. KRAWCZUK, op. cit., s. 154.

${ }^{31}$ Caes., de bello civ, 3,53,4-5: „I chcąc dać dowód swojej wytrzymałości oraz niebezpieczeństwa, donieśli Cezarowi, że na fort padło 30000 strzal, a w tarczy centuriona Scewy, którą przedstawiono wodzowi, było sto dwadzieścia dziur. Za zasługi wobec siebie i wobec rzeczpospolitej dal mu Cezar w nagrodę $20000 \mathrm{se}-$ stercjów i z ósmego stopnia przeniósł go na pierwszy; było bowiem wiadome, że utrzymanie fortu było w wielkiej mierze jego dziełem. Następnie kohorcie kazał wypłacić podwójny żołd i rozdać żołnierzom hojne nagrody w zbożu, sukniach, pieniądzach i odznaczeniach”, przekł. J. PARANDOwski, Cezar, O wojnie domowej, Warszawa 2001, s. 104. 
Dla zwycięskich wodzów niezaprzeczalnie największą nagrodą o charakterze niematerialnym ${ }^{32}$ była możliwość przeprowadzenia tryumfu lub owacji. W czasie tryumfu odbywanego za zgodą Senatu, zwycięski dowódca przemierzał ulice Rzymu na rydwanie, ubrany w haftowaną togę, $z$ wieńcem laurowym trzymanym przez niewolnika nad jego głową oraz z berłem $\mathrm{z}$ kości słoniowej w dłoni ${ }^{33}$.

Przed zaprzężonym w cztery białe konie rydwanem niesiono lupy ze zdobytych miast oraz prowadzono pojmanych wodzów. Procesja ruszała z Pola Marsowego, a kończyła się rytualną ofiarą z wołu w podzięce dla Jowisza ${ }^{34}$. W czasie tryumfu wodzowie często musieli znosić przykre docinki własnych żołnierzy, którzy w odświętnych strojach i przyozdobieni gałązkami wawrzynu, podążali na końcu pochodu. Złośliwości te miały przypominać wodzowi o jego przywarach, aby nie popadł w zbyt wielką pychę. Miały też na celu odwrócenie uwagi zawistnych bogów od wielkiego sukcesu człowieka. Podczas tryumfu Cezara podochoceni winem wojacy wypominali wielkiemu wodzowi jego rozwiązłość, przerzedzoną czuprynę, a także powtarzali plotki o młodzieńczym, homoseksualnym romansie swojego dowódcy ${ }^{35}$.

Aby otrzymać prawo organizacji tryumfu, należało jednak spełnić surowe wymogi. W walkach polec musiała określona liczba wrogów, a terytorium państwa rzymskiego musiało zostać powiększo$\mathrm{ne}^{36}$. Jeżeli takich wymogów zwycięska wojna nie spełniała, wodzowi przyznawano prawo do owacji (ovatio), obchodzonej z o wiele

${ }^{32}$ Zyski materialne zapewnialy lupy wojenne - jak choćby Lukullusowi, który po zdobyciu Tigranocerty zajął królewski skarbiec Tigranesa, por. A. KeAverneY, op. cit., s. 120.

${ }^{33}$ C. E. BRAND, op. cit., s. 108-109.

${ }^{34}$ C. E. BRAND, op. cit., s. 109.

${ }^{35}$ Suet., Jul. 49: „Wreszcie w czasie triumfu galickiego wśród innych żartobliwych piosenek, jakie śpiewają żolnierze idąc za wozem triumfalnym, slyszano i ten popularny kuplet: Cezar to Galię zniewolił, zaś Nikomedes Cezara, / Cezar dziś triumf odnosi, ten, który Galię zniewolit, / Nie Nikomedes bynajmniej, który zniewolit Cezara", przekt. J. NiemIRsKA-PLISZCZYŃsKA, op. cit., s. 33.

${ }^{36}$ C. E. BRAND, op. cit., s. 109. 
mniejszym przepychem i łączonej z poświęceniem owiec, a nie byka. Owację odbywano także zazwyczaj gdy zwycięska wojna toczona była przeciwko wrogowi „niegodnemu”, np. niewolnikom bądź piratom; lub nie została w sposób formalny wypowiedziana ${ }^{37}$. Odbywający owację przechodził przez miasto pieszo, bądź przejeżdżał konno, ubrany był skromniej, towarzyszyli mu fletniści.

Utartym zwyczajem było nadawanie przydomków zwycięskim wodzom po odbyciu tryumfu. W ten sposób honorowy tytuł uzyskał konsul Kwintus Cecyliusz Metellus po zwycięstwach w Numidii nad królem Jugurtą. Publiusz Korneliusz Scypion Młodszy w 146 roku p.n.e., po zniszczeniu Kartaginy, otrzymał przydomek Africanus, by w trzynaście lat później, po zdobyciu Numancji, uzyskać jeszcze jeden - Numantinus. Tytuły te zwykle brały swe miano od nazw pokonanych ludów lub zdobytych miast, jednakże zdarzały się inne przypadki, przykładowo Sulla po otrzymaniu dyktatury, przyjął przydomek Felix - Szczęśliwy, a Gnejusz Pompejusz po sukcesach w Afryce nazywany był Magnus - Wielkim ${ }^{38}$.

Przedstawione w niniejszym artykule nagrody i kary nie byly ujęte w żadnym wojskowym kodeksie ${ }^{39}$. Większość informacji o nich pochodzi od historyków, opisujących je niejako przy okazji relacji o najważniejszych wydarzeniach. Korzystamy więc głównie z przekazu Liwiusza, czy też Tacyta, Kasjusza Diona, Polibiusza czy Swetoniusza. Mimo wszystkich wad i nieścisłości występujących w pracach tychże historyków, rekompensują one brak źródeł prawniczych zajmujących się ściśle tematyką rzymskiego prawa wojskowego. Zbiory norm prawa wojskowego były sporządzane dopiero w czasach późnego cesarstwa, a zwłaszcza w okresie Cesarstwa Bizantyjskiego. Wiele przepisów, dotyczących spraw wojskowych, zawierają Digesta Justyniańskie ${ }^{40}$.

${ }^{37}$ A. KRawczuk, op. cit., s. 30.

${ }^{38}$ A. KRAWCZUK, op. cit., s. 147-149.

${ }^{39}$ C. E. BRAND, op. cit., s. 101-102.

${ }^{40}$ Źródłem o charakterze jurydycznym, w którym odnaleźć można wiele norm i reguł z zakresu prawa karnego wojskowego są Digesta justyniańskie, w szczególności 16 tytul 49 księgi. 
O późniejszych normach wiemy też ze „Strategici” tzw. Pseudo-Maurycjusza (VI/VII w. n.e.). Mimo więc braku całościowego skodyfikowania norm wojskowych, dzięki licznym przekazom opisującym dzieje Rzymu, możemy przekonać się, jakie znaczenie dla rozwoju potęgi imperium miały niezwykle surowe zasady karania za najdrobniejsze wykroczenia, a z drugiej strony, jak wiele osiągnięto dzięki nagradzaniu bohaterstwa i odwagi żołnierzy okazanej podczas walki.

\section{PunishmentS and ReWardS in the Roman Military LaW}

\section{Summary}

First part of the article presents an analysis of punishments in the Roman military law. The punishments may be divided into five following categories:

a) material punishments as depravation of pay;

b) reduction;

c) disgrace;

d) corporal punishments;

e) death penalty.

The second part carries a description of the rewards, that soldiers or commanders may achieve. I have analysed herein such kinds of rewards as decorations, material rewards, promotion, a Triumph and an Ovation. 